\title{
Evaluation of Marginal Percolation of the Glass Ionomer Fillings at Temporary Teeth
}

\author{
MIHAELA VALENTINA CIRDEI ${ }^{1}$, DALIANA MOCUTA ${ }^{1}$, EMILIA OGO DESCU2*, ANA PETCU3*, ANDREEA LAZEA ${ }^{1 *}$, CARMEN TODEA \\ ${ }^{1}$ Victor Babes University of Medicine and Pharmacy Timisoara, Faculty of Dentistry, Oral Rehabilitation and Dental Emergencies, \\ 2 Eftimie Murgu Sq., 300041 Timisoara, Romania \\ ${ }^{2}$ Victor Babes University of Medicine and Pharmacy Timisoara, Faculty of Dentistry, Department of Pediatric Dentistry, 2 Eftimie \\ Murgu Sq., 300041 Timisoara, Romania \\ ${ }^{3}$ Grigore T. Popa University of Medicine and Pharmacy of Iasi, 16 Universitatii Str., 700115 lasi, Romania
}

\begin{abstract}
The purpose of this in vitro study is to evaluate the marginal percolation-micro leakage by comparing the possible infiltration of ionomer cement filling which was used to restore a class I cavity prepared by classic conventional method - diamond bur versuS Er:YAG laser irradiation treatment. Ten molars were included in this study. The molars were random divided in two groups: group 1 - laser treatment and group 2-classic conventional treatments. The teeth were immersed in methylene blue solution for $24 \mathrm{~h}$. Afterwards, the molars were vestibulo-oral sectioned through the centre of each restoration in order to see any signs of marginal percolation. The marginal percolation observed was more significantin conventional preparations group than in laser's group. The glass ionomer cement remains one of the most adequate restorative materials to be used on deciduous molars when micro infiltration is questionable.
\end{abstract}

Keywords: percolation, glass ionomer cement, Er:YAG laser, primary molar

Minimally invasive methods for the optimization of the pediatric treatments are increasingly focusing on the use of laser technology. Laser therapy has been introduced into medicine in order to address the therapeutic needs of patients more quickly and effectively.

Diagnosis and assisted laser treatment allow clinicians to meet an important goal/objective in minimally invasive dentistry: filling withoutdrilling - preparing and filling cavities without milling. The replacement of dental cutters with a laser instrument that works on non-contact dental tissue without vibration, no noise and less pain, thus having a lower psychological impact on the patient, has led to the introduction of this device into pedodontics.

The pediatric dentistry is known like a field with very significance differences than general dentistry. Therefore, the approach of the patients differs in so many ways [1-4]. Treating children can be done through two methods: conventional and alternative. The conventional treatment is based on preparing the cavities using the high-speed hand piece and the alternative treatment is accessed by the laser preparation $[5,6]$.

Applications of laser systems in pedodontics depend entirely on the type of treatmentindicated and the potential benefits of these systems compared to conventional methods of treatment. Enamel and dentine of temporary teeth show differences in composition and structure versus permanent teeth. In Temporary teeth enamel is more porous and less mineralized, and enamel prisms do not have an organized spatial order. Dentine has a higher content of water but less and narrow dentine canals. Thus, for the preparation of cavities and the removal of carious lesions from temporary teeth, lower laser energy is used compared to permanent teeth.

However, certain shortcomings are present as follows: high cost, difficult accessibility, hazardous nature of laser radiation if safety precautions are not strictly observed, the impossibility of removing metal dental restorations, building the risk of thermal damage to surrounding soft tissues. Surely, the laser treatment in paediatrics will help the dentist to treat the caries lesions more conservatively which will bring better results, also gratitude and the satisfaction of those patients [7-9].

Percolation is the movement process of bacterial substances, liquids and chemicals between the tooth wall and restoration. The potential microinfiltration will resultin the discoloration of the restoration material, also will develop tooth sensibility associated with secondary decay lesion and possible the collapse of the restoration [10].

The aim of the study is to compare the clinical performance and the existence of minimal percolation throughout the two methods of cavity preparation: the classic versus Er:YAG laser preparation.

\section{Experimental part \\ Materials and methods}

This study was performed at the Department of Oral Rehabilitation and Dental Emergencies, Faculty of Dentistry in collaboration with Paediatric Dentistry section from University of Medicine and Pharmacy Victor Babes, Timisoara, Romania.

The experimental research included a collecting stage of extracted teeth from different dental clinics and an analysing part of those teeth. The selected clinics were informed on oral and written way for their role in this study and the signed informed consent for getting the teeth was obtained.

Also, the approvals of Institutional was obtained. Our study was done in accordance with the Ethical Committee of Medicine and Pharmacy "Victor Babes" University Timisoara regulations, guidelines and in accordance to some published models [11-16].

After samples selection by including and excluding criteria, only ten molars were able to be chosen in this study (fig. 1). The inclusion criteria included the absence

\footnotetext{
*email: eogodescu@gmail.com; a_ciulei@yahoo.co.uk; andreea_braia@yahoo.com
} 


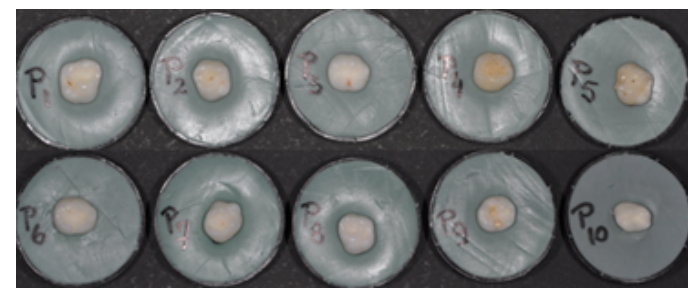

Fig. 1. The probes included in the study

of the coronal restorations, coronal cracks and caries or white spot lesions; thus, the exclusion criteria included massive coronal destruction, developed defects and any coronal changes caused by extraction method.

The samples were thoroughly cleaned and kept in a saline solution at room temperature. The molars were randomized in two groups: group 1- laser treatments (fig. 2) (Er:YAG R14, VSP, $370 \mathrm{~mJ}, 20 \mathrm{~Hz}$ - preparing process, Er:YAG R14, VSP, $80 \mathrm{~mJ}, 6 \mathrm{~Hz}$-conditioning treatment) and group 2 - conventional treatment by using a proper diamond bur (fig. 3). A Class I cavity was prepared on each molar according to the two groups $[17,18]$. The size of the cavities was also recorded. All the probes have been

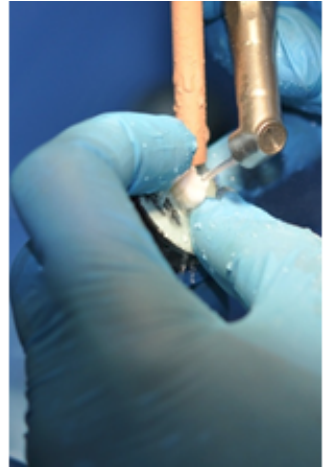

Fig. 2. Laser Cavity Preparation

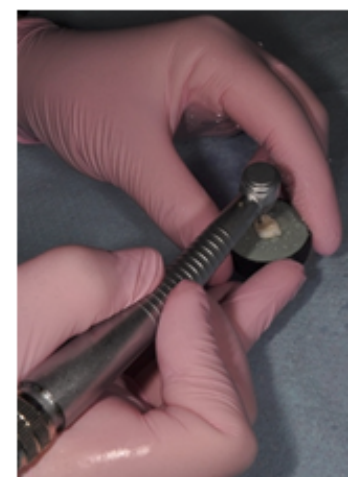

Fig. 3. Classical cavity preparation photographed in each stage by using a highly professional camera.

The main restoration material used in this study was the glass ionomer cement Fuji IX GP Capsule (GI). After each probe prepared via classic cavity preparation or laser preparation, the cavity was cleaned and dried accordingly, the cavity was conditioned with polyacrylic acid for 10 seconds and afterwards the cavity was rinsed with water and lightly dried with compressed air avoiding desiccation [19]. The GI cement(Fuji IX Capsule) was applied following the exact instructions from the producers. Over the GI filling a light coat of LC Varnish was applied and light-cured for 10 seconds [20-24]. The probes were kept in a saline solution to avoid dehydration until evaluation step.

Statistical analysis was performed by using Microsoft Excel program (2012 Windows version) and Mann-Whitney $\mathrm{U}$ test.

\section{Results and discussions}

In order to evaluate the possible percolation, few methods were accepted according to the literature [8] and those are: direct visual examination, microscopic evaluation, dye penetration, chemical tracer and photographic analysis [24]. In this study, the chosen methods were the direct visualization, the dye penetration and the photographic analysis.

Before immersing the samples into dye solution, each probe was prepared accordingly in order to evaluate the possible percolation. All the tooth surfaces were covered with two coats of nail polish with the exception of restoration surface and one $\mathrm{mm}$ zone bordering the margins of the restoration. The apical rootarea was covered with yellow wax and also painted with nail polish.

The teeth were then immersed in a $1 \%$ methylene blue solution for $24 \mathrm{~h}$. Afterwards, the molars were vestibulooral sectioned through the centre of each restoration in order to see any signs of marginal percolation (fig. 4). After sectioning process the two surfaces were photographed,
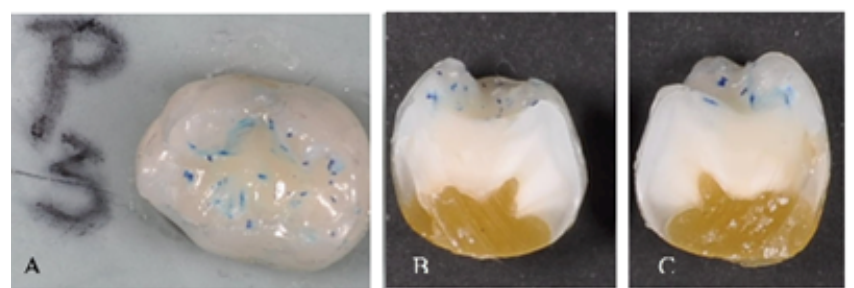

Fig. 4. The probe after the immersion $(\mathrm{A})$ and the two molar sections ( $B$ and $C$ )

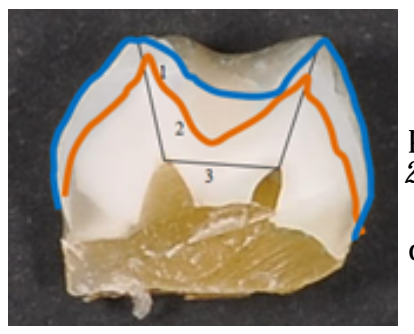

Fig. 5. The percolation grading system: Grade $0=$ no dye penetration; Grade 1 = dye penetration to enamel only; Grade $2=$ dye penetration to dentine, but not to the pulpal floor; Grade $3=$ dye penetration to the pulpal floor or the axial wall or even to the

pulp

analyzed and investigated by three examiners. A grading system (fig. 5) was used to assess dye penetration.

First of all, to calculate the normal distribution of values in vitro study results, was used Microsoft Excel program (2012 Windows version) and according to the results it was applied the Mann-Whitney $U$ test for differences determination between types of experimental treatments. Mod Laser

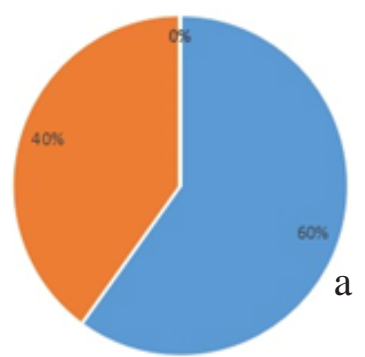
Mod Turbina

Fig. 6. The diagram results for the laser (a) and turbine (b) groups The significance level was set at $5 \%(p<0.05)$ and $95 \%$ confidence level $(p<0.05)$ ( fig. 6).

The marginal percolation observed was more significant in conventional preparations group compared with laser's group. Almostall molars presented some sort of superficial occlusal percolation. However, it was noticed that no one of the molars presented pulpal floor dye penetration.

The glass ionomer cement (Fuji IX) has a lot of advantages as follows: biocompatibility, the release of fluoride in the tooth structure and the possibility to bond directly to the prepared tooth surface. Also, using the dentine conditioner gel before restoration with GI on temporary teeth will further increase a stronger bondage between the prepared cavity surface and the glass ionomer cement [9, 21-23].

Shih WY [9] studied in 2016 the microinfiltration on temporary teeth using different restorative materials for class II cavity and he concluded that GI showed no important marginal percolation at the occlusal surface; how ever, only a $40 \%$ leakage at the cervical margins was present. In this study, it can be observed that both 
preparation methods showed a lightly marginal percolation to some probes. Therefore, itcan be said that the LC Varnish helps to prevent the microinfiltration between the tooth interface and glass ionomer cement at the occlusal level or any other surface. This can be considered a possible key factor to prevent percolation [17, 19].

Yazici [8] evaluated the clinical performance of different laser preparations techniques and the classical preparation via high speed piece of class I cavity preparation and obtained a marginal percolation rate under $5 \%$.

Also, there was no difference in marginal discoloration between the conventional versus laser preparation. Yazici also affirms from other bibliography sources that the laser preparations of class $V$ cavity present an insignificant marginal percolation versus conventional preparation.

In 2012, Baygin [25] concluded that none of the adhesive systems tested by him does eliminate the percolation entirely. The percolation was observed more towards the gingival margin than the occlusal margin. From the sources quoted by him, it appears that statistically, there was no significant difference of the percolation between the two methods of cavity preparation, laser versus classical preparation.

With another words, the marginal percolation observed in this study, was more significant to conventional preparations group than in laser's group. Also, was found that no matter which method of preparation was used, percolation was present in a more or less way; furthermore, it is important to keep in mind the conditioning step of surface either by laser or polyacrylic acid before filling the cavity with the restorative material.

The data from literature examined the effects of marginal percolating after cavities treated with lasers and conventional pre-treatment. Some studies reported that laser preparation resulted in an identical or even more obvious marginal percolation comparable to conventional preparation, but other studies had contradictory results [2426].

In 2016, Subramaniam [27] reports from his results and literature evaluation, data that laser preparation method induces changes to the enamel surface, a slight exfoliation of enamel that creates a more porous and harsh surface. This study showed that the laser preparation leaves behind a much more anfractuous and more adherent surface which made it possible to achieve a better marginal closure versus conventional preparation. Yazici [8] says in his literature-based study that the appearance of irregular and harsh surfaces due to laser treatment makes these morphological structures propitious to the adhesion of the restorative material.

According to Unal et al., in Paediatric Dentistry [28], the restorative material based on glass ionomer cements showed a minimal percolation when a laser preparation and dentine conditioning was performed.

In this experiment, was found that the samples that were prepared and conditioned only by laser withoutfurther application of polyacrylic acid did not present percolation of degree 2 or 3 , but only a marginal percolation of degree 1 or degree 0 .

According to literature data and analysed studies, the GC Fuji IX GP has a minimal percolation due to a slow cross reaction so that the material can absorb enough water from the oral cavity fluids, which helps to relieve stress that might occur in the final contraction of the glass ionomer. Thus, GC Fuji IX GP has a much better marginal sealing capacity comparable to GC Fuji II LC [29-31].

\section{Conclusions}

The glass ionomer cement Fuji IX still remains one of the most adequate restorative materials to be used on deciduous molars when micro infiltration is questionable. The marginal percolation observed in this study, was more significant to conventional preparations group than in laser's group.

\section{References}

1.GOLDBERG, M., Ann. Pediatr. Child. Health., 5, no.1, 2017, p. 1120. 2.CAPRIOGLIO, C., OLIVI, G., GENOVESE, M.D., Pediatric laser-assisted dentistry: A clinical approach, Ed.Martina, Bologna, 2010.

3.CIOLOCA, D.P., FOIA, L., HOLBAN, C., TRANDAFIRESCU, M., POROCH, V., MAXIM, D., JIPU, R., COSTULEANU, M., TOMA, V., ReV. Chim. (Bucharest), 67, no. 12, 2016, p. 2409.

4. PETCU, A., BALAN, A., GAVRILA, L. M. V., SAVIN, C., The MedicalSurgical J ournal, 118, No. 3, 2014, p. 833.

5.OLIVI, G., GENOVESE, M.D., CAPRIOGLIO, C., European Journal of Paediatric Dentistry, 10, no. 1, 2009, p. 29.

6.DOS SANTOS, G.L., BELTRAME, A.D., TRICHES, T.C., et al. J. Indian Soc. Pedod. Prev. Dent., 32, 2014, p. 130.

7.KORNBLIT, R., TRAPANI, D., BOSSU, M., et al., Eur. J. Paediatr. Dent., 9, no. 2, 2008, p. 81.

8.KOTLOW, L., General Dentistry, 56, 2008, no. 7.

9.YAZICI, A.R., BASEREN, M., GORUCU, J., Operative Dentistry, 35, no. 5,2010, p. 500.

10.SHIH, W.Y., Journal of the Chinese Medical Association, , 79, 2016, p. 228.

11.TOADER, E., TOADER, T., Revista Romana de Bioetica, 10, no. 3, 2012, p. 66.

12. TOADER, E., Revista Romana de Bioetica, 8, no. 2, 2010, p. 157.

13. SAVIN, C., TOADER, E., BALAN, G. G., GAVRILA, L. M., BALAN, A.. Revista de Cercetare si Interventie Sociala, 54, 2016, p. 156.

14. DOBRIN, R., CIOBICA, A., TOADER, E., POROCH, V., Rev. Chim. (Bucharest), 67, no. 9, 2016, p. 1778.

15.AGHEORGHIESEI CORODEANU, D.T., POROCH, V., 6th LUMEN International Conference on Rethinking Social Action Core Values, 16-19 April 2015, Iasi, Romania, Rethinking Social Action. Core Values, p. 33.

16. BALAN, G.G., TRIFAN, A., SAVIN, C., BALAN, A., GOLOGAN, E.. Revista de Cercetare si Interventie Sociala, 55, 2016, p. 244.

17.VALERIO, R.A., BORSATTO, M.C., SERRA, M.C., et al., Clin. Oral Invest., 20, no. 1, 2016, p. 65.

18.FREITAS, P.M., NAVARRO, R.S., BARROS, J.A., et al., Microscopy Research and Technique, 702, 2007, p. 803.

19.BRULAT, N., ROCCA, J.P., LEOFORESTIER, E., et al., Laser Med. Sci., 2007, Nov 22.

20.PRETEL, H., LIZARELLI, R.F., RAMALHO, L.T., Lasers Surg. Med., 39, no. 10, 2007, p. 788.

21.POLIZELI, S.A.F., VALERIO, A., NEMEZIO, M.A., et al., European Journal of Pharmaceutical and Medical Research., 3, no. 8, 2016, p. 116.

22.BOHARI, M.R., CHUNAWALLA, Y.K., AHMED, B.M.N., J. Contemp. Dent. Pract., 13, no. 1, 2012, p. 40.

23.SHANTHI, M., International J ournal of Scientific Study, 3, no. 2, 2015, p. 197.

24.BORSATTO, M.C., MARTINELLI, M.G., MARTINS, M.M., et al., Brazilian Dental Journal., 24, no. 4, 2013, p. 330.

25.BAYGIN, O., KORKMAZ, F.M., ARSLAN, I., Dental Materials J ournal., 31, no. 2, 2012, p. 206.

26.GULER, C., MALKOC, M.A., GORGEN, V.A., et al., The Scientific World J ournal, 2014, Article ID 578342.

27.SUBRAMANIAM, P., PANDEY, A., Eur. J. Dent., 8, 2014, p. 402.

28.UNAL, M., HUBBEZOGLU, I., ZAN, R., etal., Dental Materials J ournal, 32, no. 4, 2013, p. 557.

29.ASHWIN, R., ARATHI, R., J. Indian Soc. Pedod. Prev. Dent., 25, 2007, p. 86.

30.RAJU, V.G., VENUMBAKA, N.R., MUNGARA, J., et al., J. Indian Soc. Pedod. Prev. Den., 32, no. 3, 2014, p. 4.

31.MASIH, S., THOMAS, A.M., KOSHY, G., et al., J. Indian Soc. Pedod. Prev. Dent., 29, no. 1, 2011, p. 35.

Manuscript received: 14.01 .2018 